\title{
Application of social cognitive theory on maternal nutritional behavior for weight of children 6 to 12 months with Failure to thrive (FTT)
}

\section{Zainab Aghdasi}

Department of Health Education and Health Promotion, Faculty of Health, Student Research, Mashhad University of Medical Sciences, Mashhad, Iran

\section{Hadi Tehrani}

Department of Health Education and Health Promotion, Faculty of Health Mashhad University o Medical Sciences, Mashhad, Iran

Habibollah Esmaily

Department of Biostatistics, Social Determinants of Health Research Center, Mashhad University of Medical Sciences, Mashhad, Iran

Mohaddese Ghavami Department of psychology, Ferdowsi university of Mashhad, Mashhad, Iran.

Mohammad Vahedian-Shahroodi

* Department of Health Education and Health Promotion, Social Determinant of Health Research Center, Mashhad University o Medical Sciences, Mashhad, Iran. (Corresponding Author) vahedianm@mums.ac.ir

\section{Received: 2020/09/20}

Accepted: 2021/05/15

Doi: 10.52547/ijhehp.9.2.145

\begin{abstract}
Background and Objective: failure to thrive (FTT) is one of the most common and important problems in the age of 6 to 12 months. Maternal behavioral factors are the most important cause of FTT in children. One of the most important theories to improve the nutritional behaviors is social cognitive theory. This study was conducted aiming to identify the determinants of maternal nutritional behavior for children 6 to 12 months with FTT based on social cognitive theory.

Materials and Methods: This quasi-experimental study was performed with the participation of 100 mothers with children aged 6 to 12 months with FTT referred to health service centers in Torbat-Heydariye. Mothers were selected by cluster sampling and were divided into two groups of experimental and control. The educational intervention was performed in 6 sessions of 60 minutes. Data were completed using researcher-made questionnaires by mothers in three stages and analyzed by using SPSS24 software.
\end{abstract}

Results: Results showed that there was no significant difference between the two experimental and control groups before the educational intervention on score of the demographic variables. However, after educational intervention, there was a significant difference in maternal behavior and weight of child $(P<0.05)$. There was a significant difference in the scores of social cognitive theory structures before and after the intervention (awareness, outcome expectation, outcome value, task self-efficacy, self-efficacy of overcoming obstacles, self-regulation, in case of situation, emotional adaptation, modeling) in the experimental group $(P<0.05)$. Conclusion: The results after the educational intervention showed the positive effect of education based on social cognitive theory on the behavior of mothers and the weight of children 6 to 12 months with Failure to thrive (FTT) Keywords: Health education, Maternal behavior, Social cognitive theory, FTT Paper Type: Research Article.

Citation (Vancouver): Aghdasi Z, Tehrani H, Esmaily H, Ghavami M, VahedianShahroodi M. Application of social cognitive theory on maternal nutritional behavior for weight of children 6 to 12 months with Failure to thrive (FTT). Iran J Health Educ Health Promot. Summer 2021;9(2): 145-158.

> Citation (APA): Aghdasi Z., Tehrani H., Esmaily H., Ghavami M., Vahedian-Shahroodi M. (Summer 2021). Application of social cognitive theory on maternal nutritional behavior for weight of children 6 to 12 months with Failure to thrive (FTT). Iranian Journal of Health Education \& Health Promotion., 9(2), 145-158. 


\title{
كاربرد تئورى شناختى اجتماءعى بر رفتار تغذيه اى مادران و وزن كودكان و تا Fا ماهه
}

\author{
مبتلا به اختلال رشد
}

\begin{abstract}
04

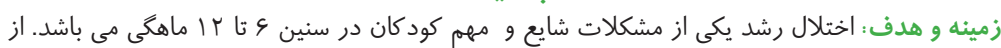

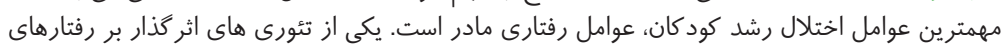

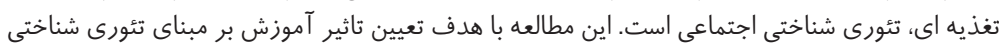

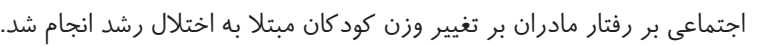

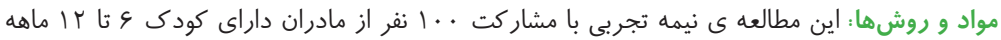

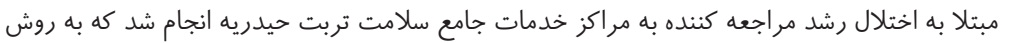

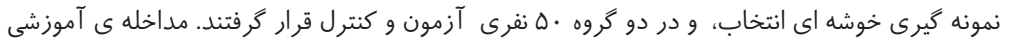

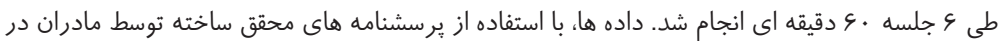
سه مرحله تكميل و به كمك نرم افزار أنسار

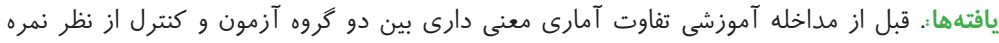

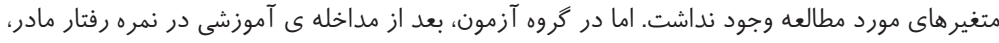

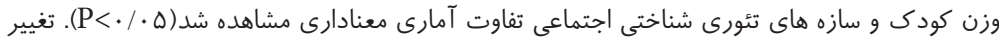

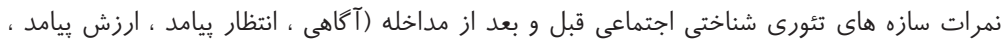

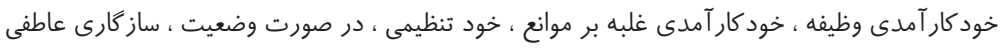

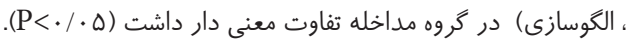

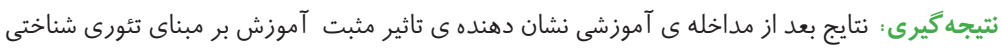

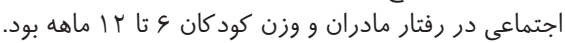

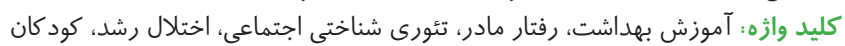
نوع مقاله : مطالعه يزوهشى.

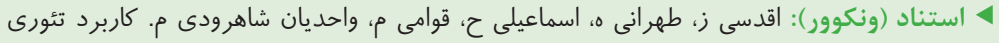

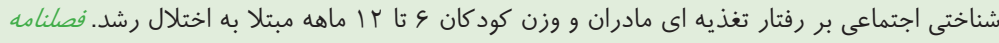

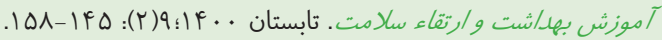

هاستناد (APA): اقدسى، زينب؛ طهر انى، هادى؛ اسماعيلى، حبيباله؛ قوامى، محدثه؛ واحديان شاهر ودىى،

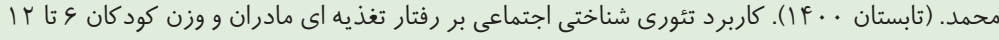

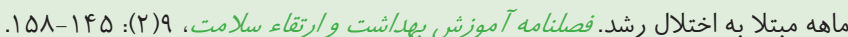

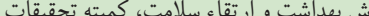
دانشجويى، دانشكاه علوم يزشكى مشهد، مشهد، ايران هادى طهر انى كروه آموزش بهداشت و ارتئاء سلامت، مركز تحقيقات

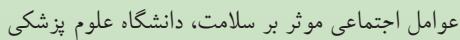

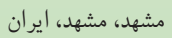
حبيب اله اسماعيلى منيلى ايران كروه آمار زيستى، مركز تحقيقات عوامل اجتماعى موثر بر سلامت، دانشخاه علوم بز شكى مشهر، مشهد، ايران

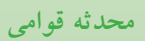
كروه روانشناسى دانشكاه فردوسى مشهد، مشهد، ايران محمد و احديان شاهرودى مرون * كروه آموزش بهداشت و ارتقاء ساء سلامت، مركز

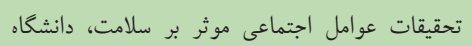

علوم يزشكى مشهد، مشهد، ايران (نو يسنده مسئول). vahedianm@mums.ac.ir

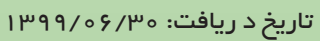

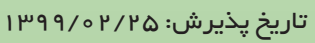


تحـــ، انگيـزش، كنجكاوى و درنتيجه تداخل كمتر كودى با

محيط، رشد و نمو ادراكى او را مختل سازد( (1).

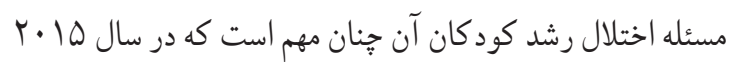
كليه كشورهاى عضو سازمان جهانى بهداشت متعهد شدند تا سال

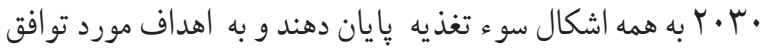
بين المللى در رابطه با كوتاه قامتى و لاغرى كودكان زير فسال

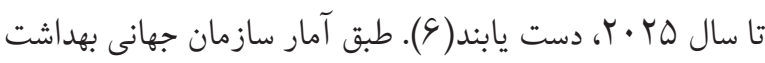

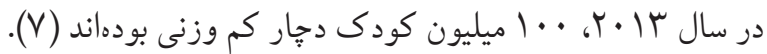
مستندات اخير نشان مىدهد كه كشورهاى در حال توسعه در

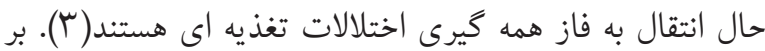
اساس مطالعه شاخصهاى جند گانه سلامت و جمعيت در ايران سال

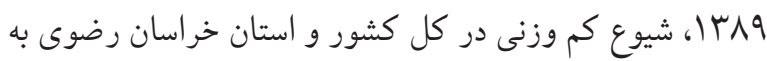

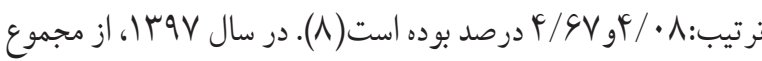

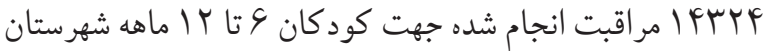
تربت حيدريه، 1/ 19 درصد اختلال رشد شناسايى شدهاند (9).

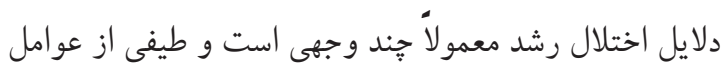

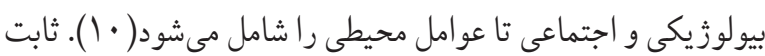

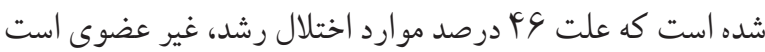
و به رفتار تغذيه اي مادر مرتبط است(و) آموزش مادر يكى از راهكارهاى اصلى بهبود رفتارهاى تغذيه اي و رشد كودكان به شمار

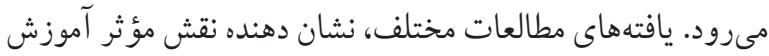

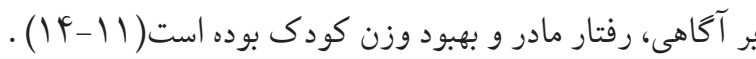

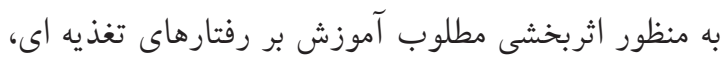

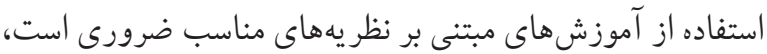

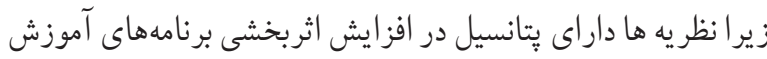

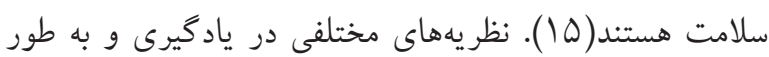

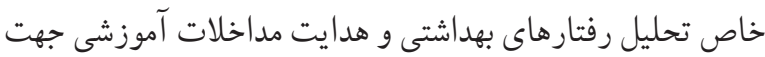
ارتقاى رفتار سلامت وجود دارد يكى از كار آمدتر ين نظريهها براى مهاى

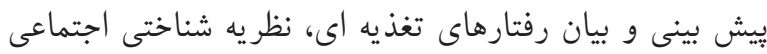
(Social Cognitive Theory)
فقر غذايى يكى از مسائل مهم رفاه و سلامتى است. اين وضعيت شامل سه جزء اصلى سوء تغذيه شامل: كوتاه براى سن، كم وزن

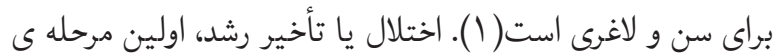
بروز كم وزنى و يكى از مشكلات شايع و مهم بهداشتى در دوران كودكى است. منظور از اختلال رشد، كاهش تدريجى سرعت رشد از

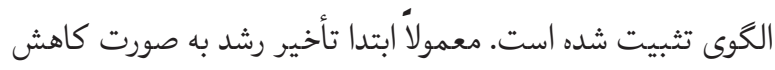

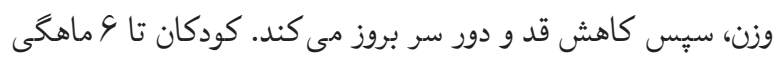

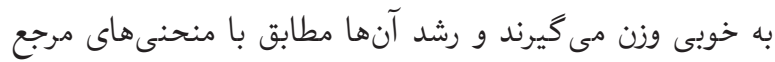
است ولى با افزايش سن، ميزان شيوع كم وزنى افزايش مى يابد(Y).

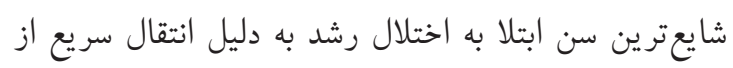
تغذيه انحصارى با شير مادر به مصرف ساير گروههاى غذايى 9 تا

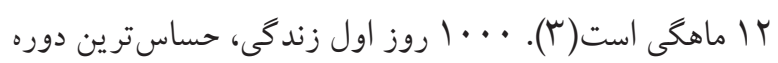

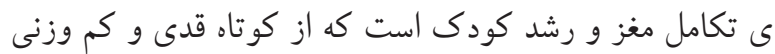
اوليه بيشخيرى مى كند. به طور كلى سوء تغذيه، بيامدهاى كوتاه

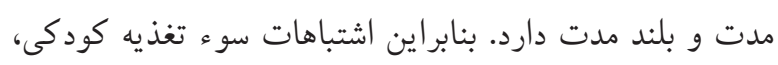

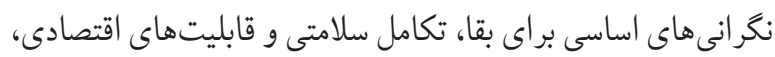

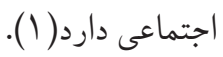
سوء تغذيه منجر به اختلال در مكانيسمهاى دفاعى او مىشود.

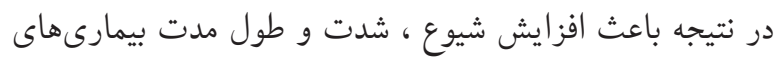

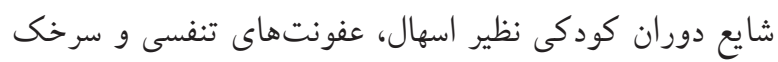
مىشود و از طرفى منجر به بهبود كندتر و ميرايى بيشتر ايشان

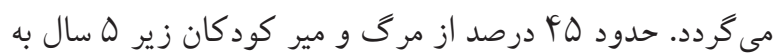

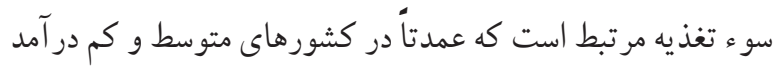

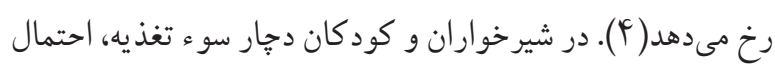

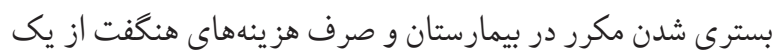

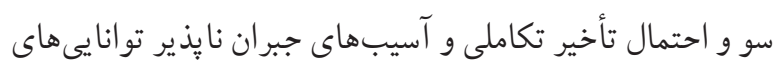
شناختى و تحصيلى از سوى ديخر به شدت افزايش مى يابد(ه).

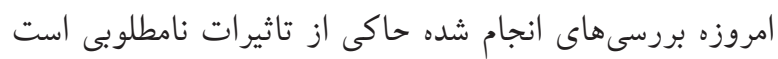

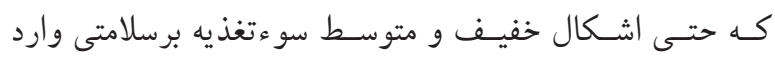

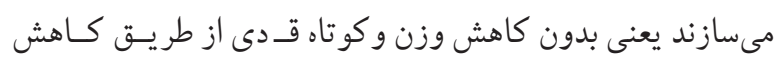


زير با استناد به مقاله گلشيرى و همكاران ( •(T)، با در نظر كرفتن

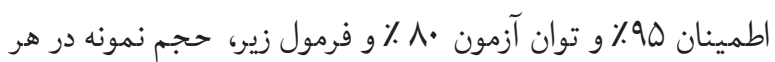

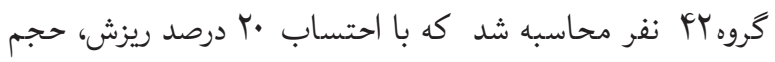

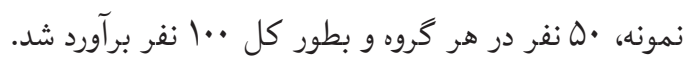
$n=\frac{\left(Z_{\uparrow-\frac{\alpha}{r}}+Z_{\uparrow-\beta}\right)^{\curlyvee}\left(\delta_{\uparrow}^{\curlyvee}+\delta_{\uparrow}^{r}\right)}{\left(\mu_{\uparrow}-\mu_{\curlyvee}\right)^{\curlyvee}}$

قابل ذكر است پِ از انجام مداخله، ب نفر از هر كروه آزمون

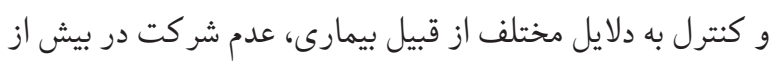
يك جلسه و عدم تمايل به ادامه ى مطالعه حذف شدند. نحوه انجام نمونه كيرى

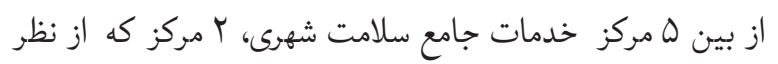
شرايط اجتماعى، اقتصادى و موقعيت جغرافيايى مشابه بودند به هردئ

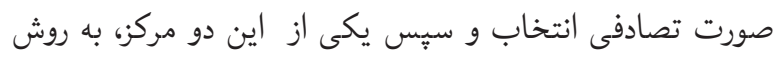

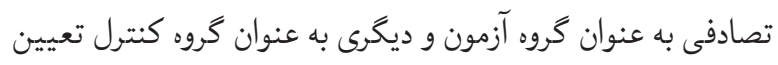

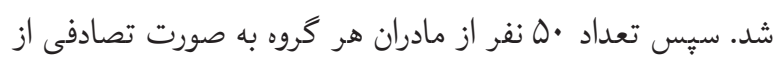
مراكز آزمون و كنترل كزينش شدند. كودكان اين مادران(گروه كنترل

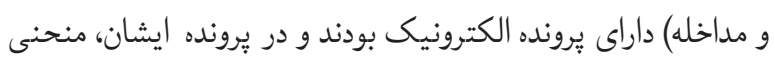

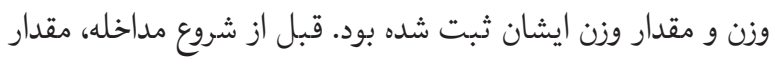

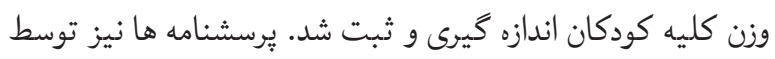

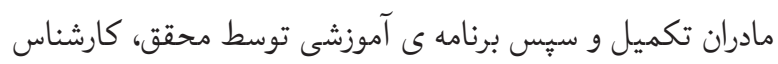
ارشد روانشناسى بالينى و كارشناس تغذيه جهت گروه آزمون اجرا شد.

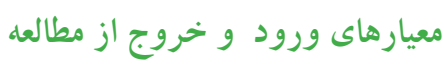
مادران داراى حداقل يك كودى 9 ماه تا يك سال كه در آخرين

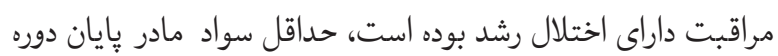
ابتدايى باشد، تمايل به شركت در مطالعه داشته باشند، دانش آموخته

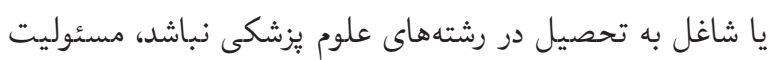

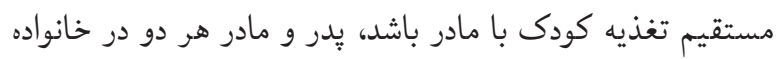

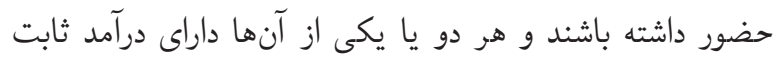

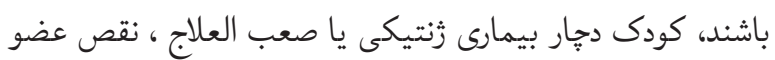

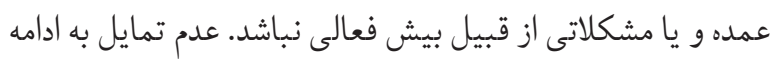
همكارى غيبت بيش از يك جلسه آموزشى، نقل مكان مادر و عدم
تاكيد دارد كه خصوصيات فردى و محيطى بر رفتار اثر مى گذارند و معتقد به اصول تعيين كنندگى متقابل است.

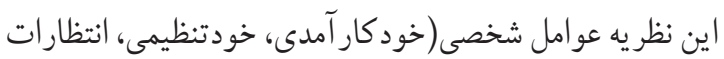

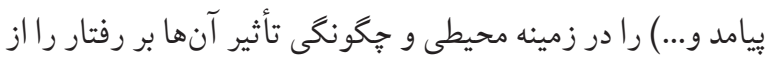

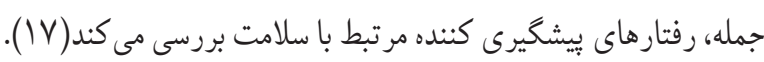

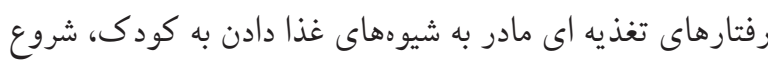

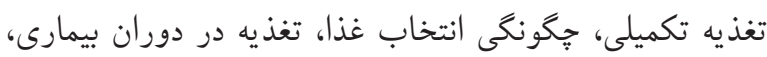

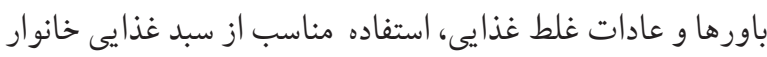

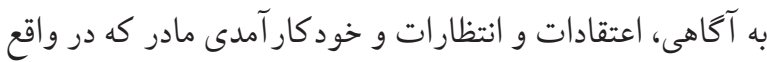
عوامل شناختى مادر هستند و نيز دسترسى به مواد غذايى، حمايت

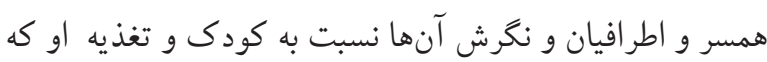
تشكيل دهنده عوامل محيطى هستند، مرتبط مىباشد. بررسى اين

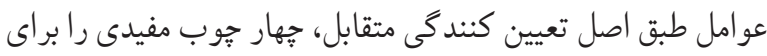

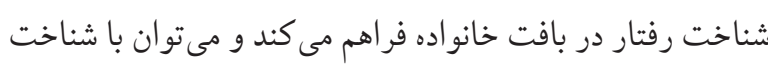

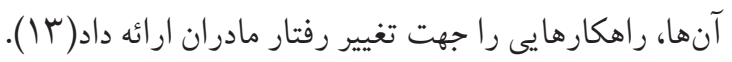
نظر يه شناختى اجتماعى در بر رسى رفتارهاى مختلف تغذيه به راهيه كار رفته است. بسيارى از برنامههاى موفق بهبود تغذيه در كود كان

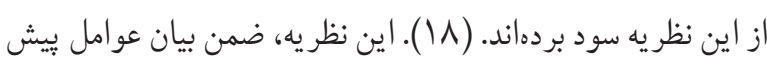

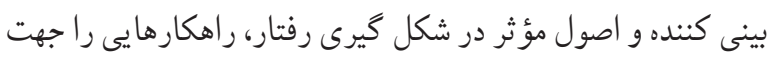

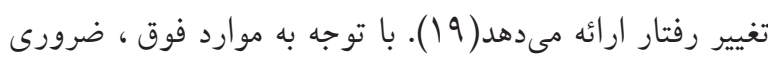

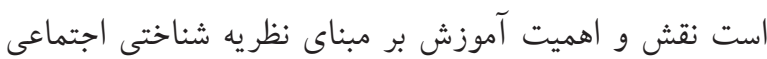
كه فر آيندهاى شناختى - محيطى از جمله ياد كيرى مشاهدهاى و و

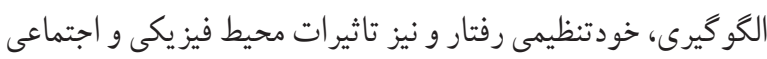

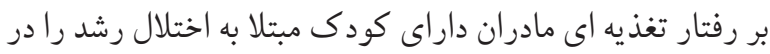

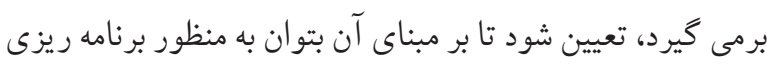

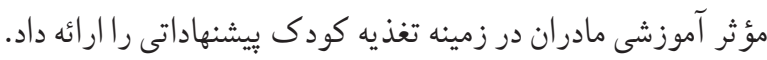

$$
\text { مو اد و روشها - ماد }
$$
حجم نمونه در اين مطالعه مداخله اي كه در سال 99 در مراكز خدمات جامع سلامت شهر تربت حيدريه انجام شد، حجم نمونه با استفاده از فرمول مرل مرداب 
يزم)، خود تنظيمى( أ گويه)(مثلا براى تهيه غذاى كمكى سالم براى

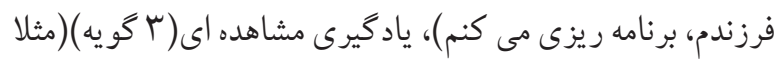

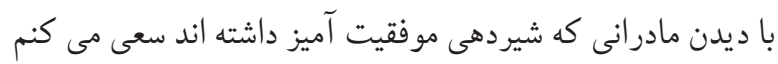
در اين زمينه تلاش بيشترى انجام دهم)، ساز كارى عاطفى (ب كويه) (مثلازمانى كه كودكم وزن كيرى كافى دارد خوشحال مى شوم) و

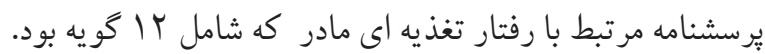

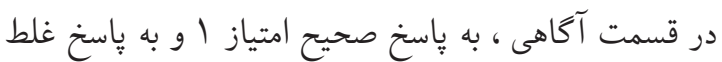

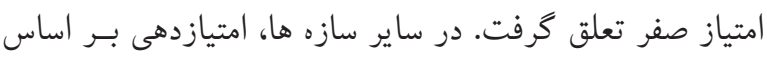

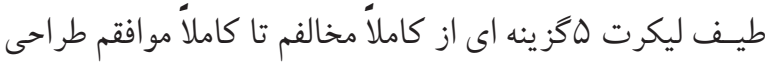

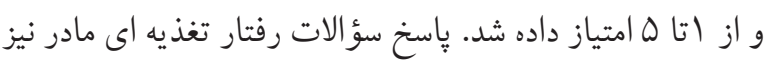
در صورت صحيح بودن امتياز ا و براى ياسخ غلط، امتيازى در نظر كرفته نشد.

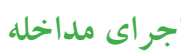
مداخله ى آموزشى بر مبناى استراتزىها و اصول نظريه شناختى

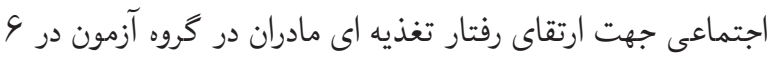

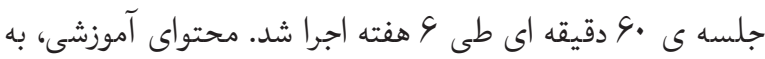

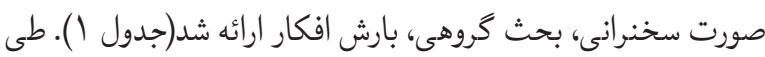

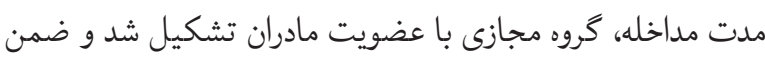

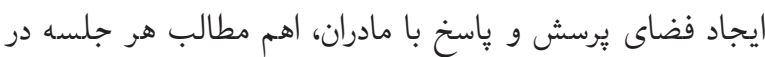

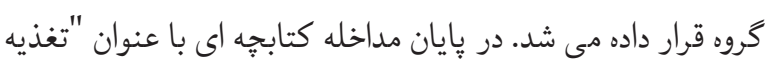

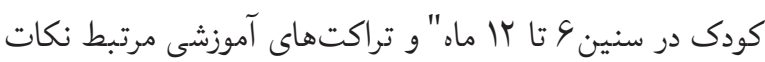
مهم تغذيه كودى داراى اختلال رشد كه توسط مجرى بروره تهيه شده

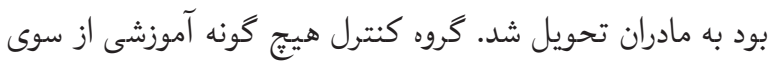

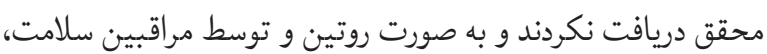

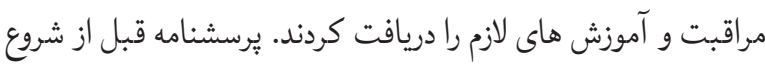
مداخله توسط مادران تكميل شد. تاثير برنامه آموزشى بلافاصله و

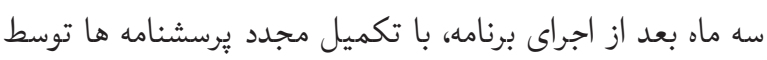

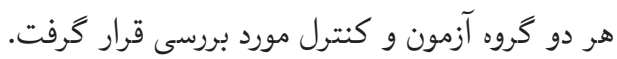

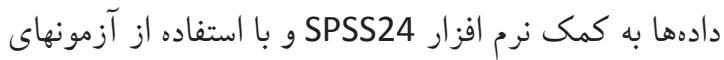

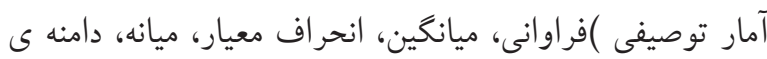

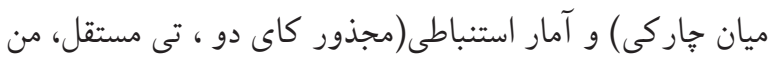

دسترسى به ايشان ، ابتلا كودى به بيمارى حاد طى دوره يُزوهش معيار خروج از يُزوهش در نظر كرفته شد.

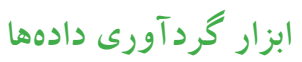
اين ابزار، شامل سه بخش بود. يرسشنامه ى اطلاعات جمعيت

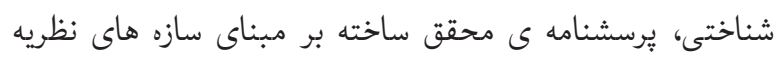

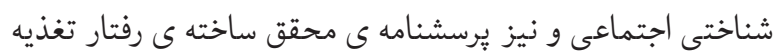
اى مادر بود. يرسشنامههاى محقق ساخته پِ از بروسى متون و و

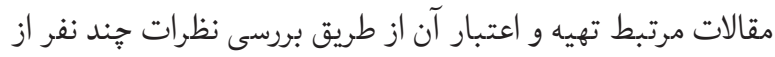

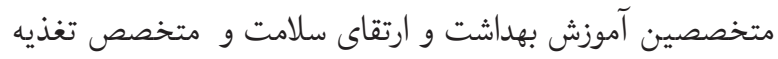
و با سنجش اعتبار محتوايى' و شاخص روايى محتوا'مورد تأييد

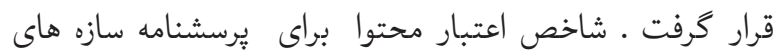

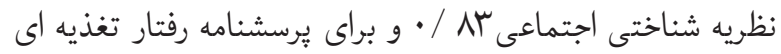

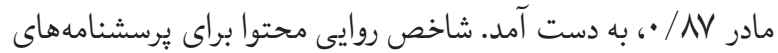

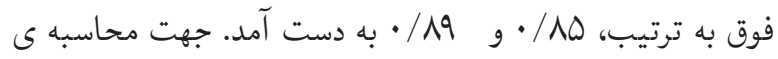

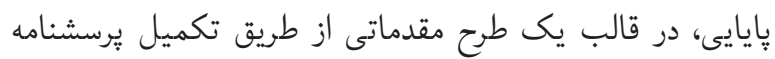

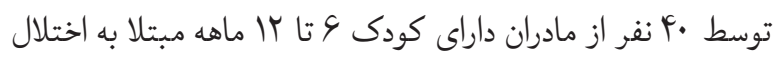

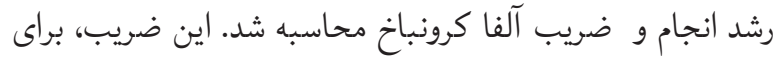
هر دو برسشنامه بيش از V/ • بدست آمد.

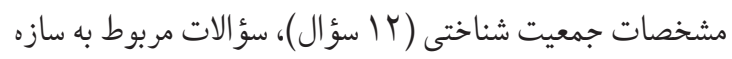

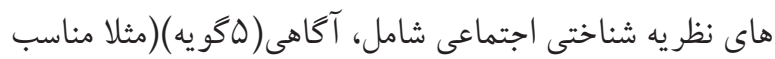

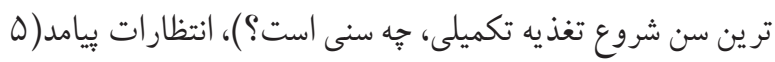

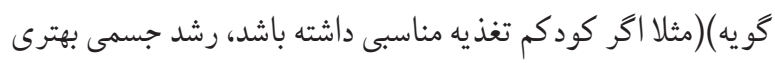
خواهد داشت)، ارزش يبامد( أ كويه)(مثلا مهم است كه كودكم از

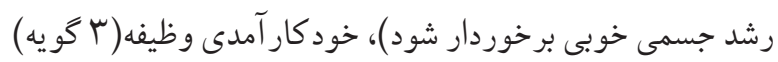

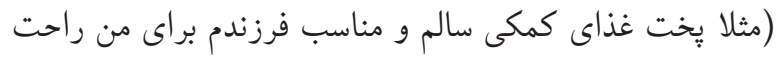

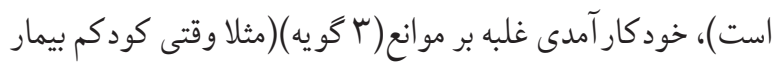

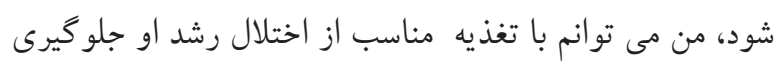

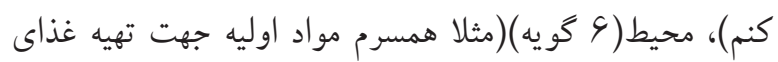

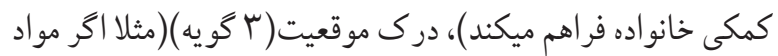
غذايى در دسترس باشد من هر روز براى كودى غذاى كمكى مى ديى

1. Content validity ratio(CVR)

2. Content-validity index(CVI) 
جدول ا. جلسات آموزش، محتوى و روش هاى آموزشى جهت انجام مداخله

\begin{tabular}{|c|c|c|}
\hline 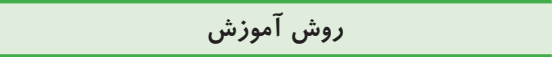 & محتواى آموزشى & 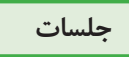 \\
\hline سخنرانى، بحث گروهى و پرسش و پاسخ & اختلال رشدو نحوه تشخيص اختلال رشد، اهميت رشد دوران كودكى، نقش تغذيه در & جلسه اول \\
\hline سخنرانى، بحث گروهى و يرسش و پاسخ، بارش افكار & 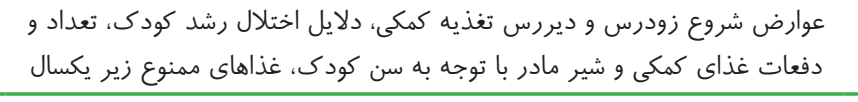 & جلسه دوم \\
\hline سخنرانى، بحث گروهى و هر سش و پاسخ، نمايش عملى & 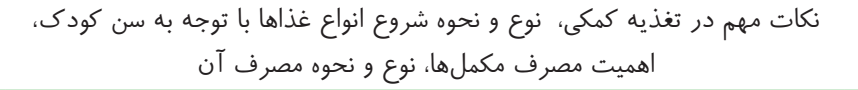 & 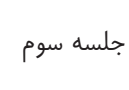 \\
\hline سخنرانى، بارش افكار، بحث گروهى و يرسش و پِاسخ، & مشكلات و موانع رفتار تغذيه اى مطلوب، تكامل كودى و وارتباط ردان تغذيه با آن، & جلسه جهارم \\
\hline سخنرانى، بحث گروهى و يرسش و پاسخ، نمايش فيلم و نملى & 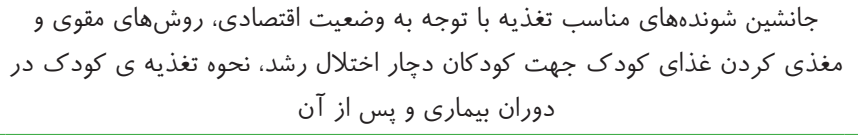 & جلسه ينجم \\
\hline سخنرانى، بحث گروهى و ِرسش و پاسخ، ايفاى نقش & مديرت استرس، علل، نشانهها، روشهاى مقابله با آن، مهارت تصميم گيرى، مديريت & 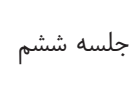 \\
\hline
\end{tabular}

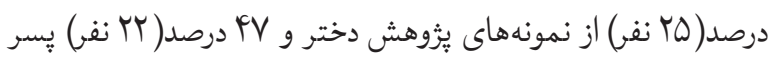

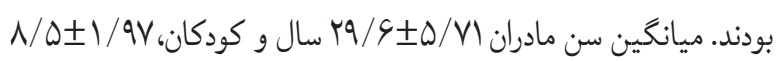

ماه بود. 91 درصد (FF FF نف مادران خانه دار بودند و تحصيلات

$$
\text { درصد(ب نفى) از آنها دبيرستان و دييلم بود. }
$$

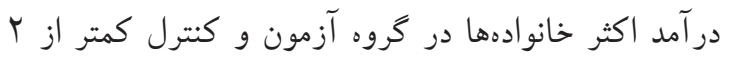

بافْته ها

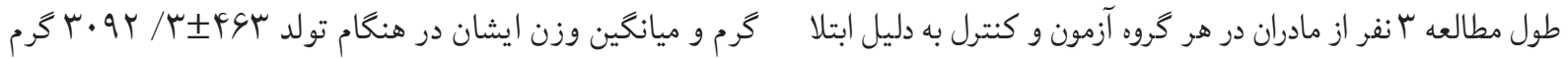
كودى به بيمارى از مطالعه حذف شدند. در نهايت اطلاعات Fٔ مادر بود. نتايج نشان داد بين دو گروه آزمون و كنترل تفاوت معنادارى

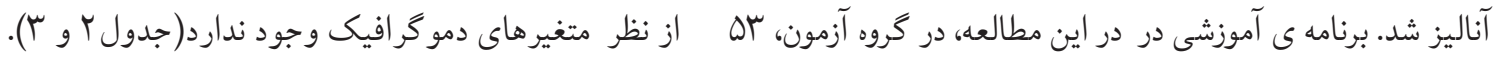

جدول r. متغيرهاى كيفى جمعيتى شناختى در گروه هاى تحت مطالعه قبل از مداخله آموزشى در دو گروه

\begin{tabular}{|c|c|c|c|c|}
\hline نتيجه آزمون دو) & كنترل & آزمون & \multirow{2}{*}{\multicolumn{2}{|c|}{ متغير }} \\
\hline P-Value & تعداد (درصد) & تعداد (درصد) & & \\
\hline \multirow{2}{*}{$\begin{array}{c}X^{2}=\cdot / \cdot \mu r \\
P=\cdot / \lambda \mu\end{array}$} & $(\Delta \Delta / \Gamma) r G$ & $(\Delta \mu / r) \Gamma \Delta$ & دختر & \multirow{2}{*}{ جنس كودى } \\
\hline & $(F F / V) Y I$ & $(F G / \Lambda) Y r$ & 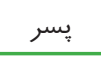 & \\
\hline \multirow{2}{*}{$\begin{array}{c}X^{2}=1 / \Delta r \\
P=\cdot / r \mid\end{array}$} & $(\Lambda \mu / \cdot) \mu q$ & $(91 / \Delta) \& r$ & خانه دار & \multirow{2}{*}{ شغل مادر } \\
\hline & $(\mid \vee / \cdot) \Lambda$ & $(\Lambda / \Delta)^{q}$ & شاغل & \\
\hline \multirow{4}{*}{$\begin{array}{l}X^{2}=r / V \wedge \\
P=\cdot / \mathscr{r} \varsigma\end{array}$} & $(\varsigma / \mathcal{F}) \boldsymbol{r}$ & $(r / 1) 1$ & بيكار & \multirow{4}{*}{ شغل پيدر } \\
\hline & $(r V / V) \backslash r$ & $(Y r / F) \backslash 1$ & كارمند & \\
\hline & $(\mathrm{V} / \cdot) \wedge$ & $(1 \cdot / 9) 0$ & كارگر & \\
\hline & $(F \wedge / q) r r$ & 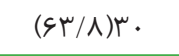 & آزاد & \\
\hline
\end{tabular}




\begin{tabular}{|c|c|c|c|c|}
\hline \multirow{4}{*}{$\begin{array}{l}X^{2}=\cdot / \Delta \Lambda \\
P=\cdot / 4 \notin \varphi\end{array}$} & $(\mid r / \Lambda) \xi$ & $(1 \cdot / \varsigma) \Delta$ & ابتدايى & \multirow{4}{*}{ تحصيلات مادر } \\
\hline & $(r \mu / F) \mid r$ & $(r \mid / r))$. & راهنمايى & \\
\hline & $(F F / V) Y \Delta$ & $(r G / \Lambda) r r$ & دبيرستان و دييلم & \\
\hline & $(19 / 1) 9$ & $(r \mid / r) 1$. & دانشگاهى & \\
\hline \multirow{4}{*}{$\begin{array}{l}\mathrm{X}^{2}=\cdot / \mathcal{A} \wedge \\
\mathrm{P}=\cdot / \mathcal{A} \wedge \mathcal{G}\end{array}$} & $(\mid \mathrm{V} / \cdot) \Lambda$ & $(\mid F / 9) V$ & ابتدايى & \multirow{4}{*}{ تحصيلات يدر } \\
\hline & $(r V / v) \backslash r$ & $(r q / \wedge) \backslash r$ & راهنمايى & \\
\hline & 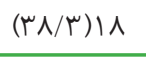 & $(r F / \cdot) \mid S$ & دبير ستان و ديیلم & \\
\hline & $(\mid \mathrm{V} / \cdot) \wedge$ & $(r \mid / r) \mid \cdot$ & دانشگاهى & \\
\hline \multirow{4}{*}{$\begin{array}{l}X^{2}=r / V \Lambda \\
P=\cdot / \Psi r V\end{array}$} & $(r \mid / r) \mid \cdot$ & $(\mathrm{IV} / \cdot) \Lambda$ & كمتر از يك ميليون تومان & \multirow{4}{*}{ در آمد ماهانه خانواده } \\
\hline & $(\Delta 9 / \varepsilon) r \wedge$ & $(D I / I) F F$ & بين ا تا r ميليون تومان & \\
\hline & $(1 \cdot / 4) \Delta$ & $(r \mu / F) \backslash 1$ & بين r تا r ميليون تومان & \\
\hline & $(\Lambda / \Delta) F$ & $(\Lambda / \Delta) \uparrow$ & بيش از ץ ميليون تومان & \\
\hline
\end{tabular}

جدول سّ. متغيرهاى دمو گرافيك كمى در گروه هاى تحت مطالعه قبل از مداخله آموزشى

\begin{tabular}{|c|c|c|c|}
\hline \multirow{2}{*}{ تتى مستقل آزمون } & كنترل & آزمون & \multirow{2}{*}{ متغير } \\
\hline & انحراف معيار 土 ميانگين & انحراف معيار 土 ميانگين & \\
\hline $\begin{array}{l}\mathrm{t}=\cdot / \Delta \mid \\
\mathrm{P}=\cdot / \Delta Y\end{array}$ & 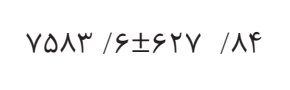 & $V F q r \pm q \cdot G \cdot / 4$ & وزن كودك \\
\hline $\begin{array}{l}t=\cdot / \Delta q \\
P=\cdot / \Delta \Delta\end{array}$ & rN/A $\pm S / G$ & $r q / \varsigma \pm \Delta / \Lambda$ & سن مادر \\
\hline $\begin{array}{c}\mathrm{Z}=\cdot / \varsigma \mathrm{V} \\
\mathrm{P}=\cdot / \Delta\end{array}$ & $\wedge / \wedge I \pm 1 / \Lambda$ & $\Lambda / \Delta \pm 1 / q$ & سن كودك \\
\hline $\begin{array}{l}\mathrm{Z}=\cdot / \Delta \mathrm{Y} \\
\mathrm{P}=\cdot / \Delta \Lambda\end{array}$ & $1 / V \pm \cdot / \Lambda$ & $1 / V \pm \cdot / V$ & رتبه تولد كودى \\
\hline $\begin{array}{l}\mathrm{Z}=\cdot / \Delta \mu \\
\mathrm{P}=\cdot / \Delta q\end{array}$ & $1 / V Y \pm \cdot / \Lambda$ & $1 / V \pm \cdot / V$ & تعداد فرزندان \\
\hline $\begin{array}{l}\mathrm{t}=\cdot / \vee q \\
\mathrm{P}=\cdot / \uparrow q\end{array}$ & $r \cdot r r / r \pm r V I$ & $r \cdot q r / r \pm r q \mu$ & وزن تولد كودى \\
\hline
\end{tabular}

در اين مطالعه كليه ى متغيرها و سازه هاى نظريه شناختى - درك موقعيت، ساز كارى عاطفى، الكوسازى) بلافاصله و سه ماه اجتماعى به جز متغير وزن در هر سه مرحله ى قبل، بلافاصله و بعد نسبت به قبل از مطالعه تفاوت معنى دارى در دو گروه مشاهده

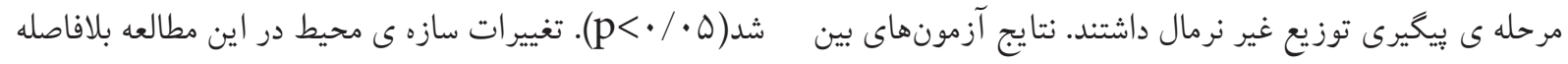

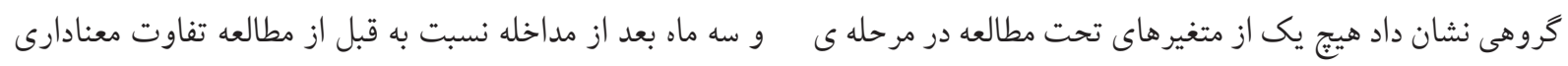

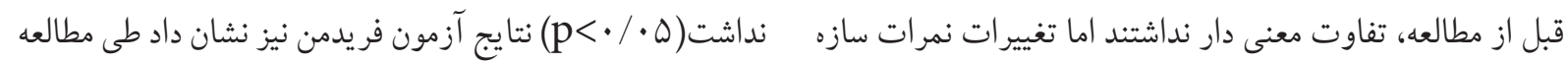

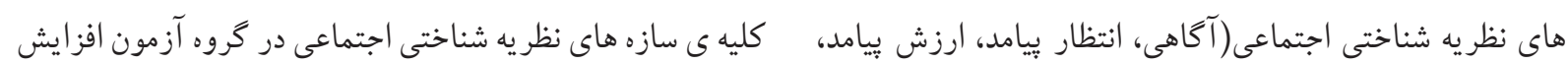

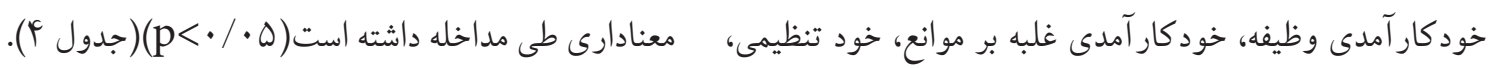


جدولعا. تغييرات ميانه و دامنه ميان جاركى سازه هاى نظريه شناختى اجتماعى در گروههاى آزمون و كنترل ، قبل، بلافاصله و سه ماه بعد از مداخله آموزشى

\begin{tabular}{|c|c|c|c|c|}
\hline \multirow{3}{*}{$\begin{array}{l}\text { (من ويتنى) } \\
\text { P-value }\end{array}$} & كروه كنترل & كروه آزمون & \multirow{3}{*}{ 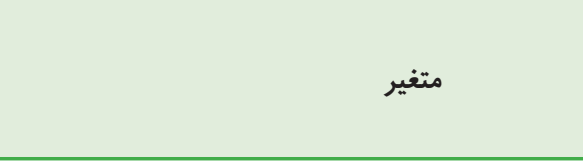 } & \\
\hline & \multicolumn{2}{|c|}{ (دامنه ميان جار كى) (دامنه ميان جاركى) } & & \\
\hline & ميانه & ميانه & & \\
\hline $\begin{array}{l}Z=-r / 0 \cdot r \\
P<\cdot / \cdots 1\end{array}$ & $\cdot(\cdot)$ & $1(r)$ & تغييرات بلافاصله نسبت به قبل مداخله & \multirow{4}{*}{ 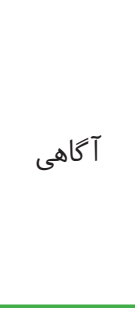 } \\
\hline \multirow[t]{3}{*}{$\begin{array}{l}\mathrm{Z}=-\boldsymbol{F} / \Delta F \mid \\
\mathrm{P}<\cdot / \cdots 1\end{array}$} & $1(\cdot)$ & $r(r)$ & تغييرات سه ماه بعد از مداخله نسبت به قبل مداخله & \\
\hline & $X^{2}=\cdot / 10$ & $X^{2}=\Delta r / F \mid V$ & \multirow{2}{*}{ 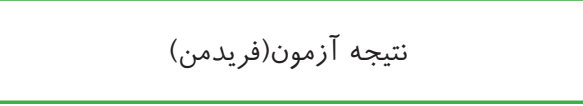 } & \\
\hline & $\mathrm{p}=\cdot / \cdot r$ & $\mathrm{P}<\cdot / \cdots 1$ & & \\
\hline $\begin{array}{l}\mathrm{Z}=-\Delta / \wedge 9 \\
\mathrm{p}<\cdot / \cdots 1\end{array}$ & $\cdot(\cdot)$ & $r(1)$ & تغييرات بلافاصله نسبت به قبل مداخله & \multirow{3}{*}{ 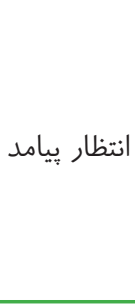 } \\
\hline \multirow[t]{2}{*}{$\begin{array}{l}\mathrm{Z}=-\varsigma / r q \\
\mathrm{p}<\cdot / \cdots 1\end{array}$} & $\cdot(\cdot)$ & $r(r)$ & تغييرات سه ماه بعد از مداخله نسبت به قبل مداخله & \\
\hline & $\begin{array}{c}X^{2}=1 r / 10 \\
p=\cdot / \cdot r\end{array}$ & $\begin{array}{c}X^{2}=\Delta r / \mathcal{F} \mid V \\
\mathrm{P}<\cdot / \cdots 1\end{array}$ & نتيجه آزمون(فريدمن) & \\
\hline $\begin{array}{l}\mathrm{Z}=-\Delta / \mathrm{V}) \\
\mathrm{p}<\cdot / \cdots 1\end{array}$ & $\cdot(\cdot)$ & $1(1)$ & تغييرات بلافاصله نسبت به قبل مداخله & \multirow{3}{*}{ ارزش بِيامد } \\
\hline \multirow[t]{2}{*}{$\begin{array}{l}\mathrm{Z}=-\Delta / \mu \mu \\
\mathrm{p}<\cdot / \cdots 1\end{array}$} & $\cdot(\cdot)$ & $r(\cdot)$ & تغييرات سه ماه بعد از مداخله نسبت به قبل مداخله & \\
\hline & $\begin{array}{l}X^{2}=r / \Lambda I \\
p=\cdot / r F\end{array}$ & $\begin{array}{c}X^{2}=\Delta G / \mu \\
p<\cdot / \cdots 1\end{array}$ & نتيجه آزمون(فريدمن) & \\
\hline
\end{tabular}

\begin{tabular}{|c|c|c|c|c|}
\hline $\begin{array}{l}\mathrm{Z}=-\mu / \mathcal{\mu} \Delta \\
\mathrm{p}=\cdot / \cdots\end{array}$ & $\cdot(\cdot)$ & $\cdot(\cdot)$ & تغييرات بلافاصله نسبت به قبل مداخله & \multirow{3}{*}{ خود كار آمدى وظيفه } \\
\hline $\begin{array}{l}\mathrm{z}=-r / \cdot r \\
\mathrm{p}=\cdot / \cdot r\end{array}$ & $\cdot(\cdot)$ & $1(\cdot)$ & تغييرات سه ماه بعد از مداخله نسبت به قبل مداخله & \\
\hline & $\begin{aligned} X^{2} & =1 / \cdot r \\
p & =\cdot / 09\end{aligned}$ & $\begin{array}{l}\mathrm{p}<\cdot / \cdots 1 \\
X^{2}=r \Delta / \mu r\end{array}$ & نتيجه آزمون(فريدمن) & \\
\hline $\begin{array}{l}\mathrm{z}=-\mathrm{r} / \Lambda \\
\mathrm{p}<\cdot / \cdot \cdot 1\end{array}$ & $\cdot(\cdot)$ & $r(\cdot)$ & تغييرات بلافاصله نسبت به قبل مداخله & \\
\hline \multirow[t]{2}{*}{$\begin{array}{c}z=-r / q \\
p<\cdot / \cdots l\end{array}$} & $\cdot(\cdot)$ & $r(\cdot)$ & تغييرات سه ماه بعد از مداخله نسبت به قبل مداخله & خود كار امدى غلبه بر \\
\hline & $\begin{array}{l}X^{2}=r / \Lambda V \\
p=\cdot / r r\end{array}$ & $\begin{array}{l}X^{2}=r \cdot / 9 V \\
p<\cdot / \cdots 1\end{array}$ & 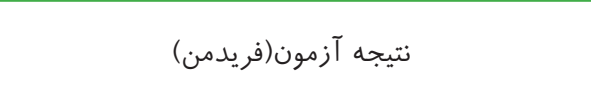 & \\
\hline $\begin{array}{l}z=-1 / \uparrow \Delta \\
p=\cdot / 1 \uparrow \Delta\end{array}$ & $1(\cdot)$ & $r(\cdot)$ & تغييرات بلافاصله نسبت به قبل مداخله & \multirow{3}{*}{ محيط } \\
\hline $\begin{array}{l}z=-1 / r r \\
p=\cdot / 1 \wedge \varphi\end{array}$ & $1(\cdot)$ & $r(\cdot)$ & تغييرات سه ماه بعد از مداخله نسبت به قبل مداخله & \\
\hline & $\begin{array}{l}X^{2}=r / \Lambda V \\
p=\cdot / r r\end{array}$ & $\begin{array}{l}X^{2}=r \cdot / 9 V \\
p<\cdot / \cdot 1\end{array}$ & نتيجه آزمون(فريدمن) & \\
\hline
\end{tabular}




\begin{tabular}{|c|c|c|c|c|}
\hline $\begin{array}{l}\mathrm{Z}=-\Delta / \varsigma \mu \\
\mathrm{p}<\cdot / \cdots l\end{array}$ & $\cdot(\cdot)$ & $r(\cdot)$ & تغييرات بلافاصله نسبت به قبل مداخله & \\
\hline $\begin{array}{l}\mathrm{z}=-s / f \mid \\
\mathrm{p}<\cdot / \cdots 1\end{array}$ & $\cdot(-r)$ & $F(1)$ & تغييرات سه ماه بعد از مداخله نسبت به قبل مداخله & درك موقعيت \\
\hline & $\begin{array}{l}X^{2}=V / \Delta r \\
p=\cdot / \cdot r r\end{array}$ & $\begin{array}{c}X^{2}=r q / F \mid \\
p<\cdot / \cdots l\end{array}$ & نتيجه آزمون(فريدمن) & \\
\hline
\end{tabular}

\begin{tabular}{|c|c|c|c|c|}
\hline $\begin{array}{l}z=-9 / \cdot q \\
p<\cdot / \cdot \cdot 1\end{array}$ & $\cdot(\cdot)$ & $F(r)$ & تغييرات بلافاصله نسبت به قبل مداخله & \multirow{3}{*}{ خودتنظيمى } \\
\hline $\begin{array}{l}\mathrm{z}=-\varsigma / \mathrm{r} \wedge \\
\mathrm{p}<\cdot / \cdots l\end{array}$ & $-1(\cdot)$ & $r(r)$ & تغييرات سه ماه بعد از مداخله نسبت به قبل مداخله & \\
\hline $\begin{array}{l}\mathrm{Z}=-\Delta / \varsigma^{\mu} \\
\mathrm{p}<\cdot / \cdots 1\end{array}$ & $\begin{array}{c}\mathrm{X}^{2}=r / V q \\
\mathrm{p}=\cdot / 10\end{array}$ & $\begin{array}{l}X^{2}=\Delta \Delta / \cdot V \\
p<\cdot / \cdot \cdot 1\end{array}$ & نتيجه آزمون(فريدمن) & \\
\hline $\begin{array}{l}Z=-\mu / \mu^{\mu} \\
p<\cdot / \cdot \text { l }\end{array}$ & $\cdot(\cdot)$ & $r(\cdot)$ & تغييرات بلافاصله نسبت به قبل مداخله & \multirow{3}{*}{ 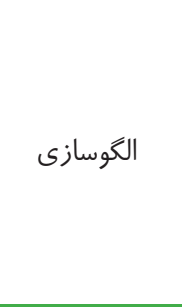 } \\
\hline $\begin{array}{l}z=-\boldsymbol{r} / \cdot \Delta \\
\mathrm{p}<\cdot / \cdot \cdot 1\end{array}$ & $\cdot(-1)$ & $1(\cdot)$ & تغييرات سه ماه بعد از مداخله نسبت به قبل مداخله & \\
\hline & $\begin{array}{l}X^{2}=r / 1 r \\
p=\cdot / I r\end{array}$ & $\begin{array}{l}X^{2}=m y / V I \\
p<\cdot / \cdots 1\end{array}$ & نتيجه آزمون(فريدمن) & \\
\hline $\begin{array}{l}z=-s / f \mid \\
\mathrm{p}<\cdot / \cdot \cdot 1\end{array}$ & $\cdot(\cdot)$ & $r(1)$ & تغييرات بلافاصله نسبت به قبل مداخله & \multirow{3}{*}{ ساز كارى عاطفى } \\
\hline $\begin{array}{l}\mathrm{Z}=-4 / V V \\
\mathrm{p}<\cdot / \cdots 1\end{array}$ & $\cdot(-1)$ & $1(\cdot)$ & تغييرات سه ماه بعد از مداخله نسبت به قبل مداخله & \\
\hline & 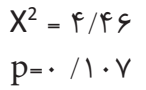 & $\begin{array}{c}\mathrm{X}^{2}=s \uparrow / \Delta \wedge \\
\mathrm{p}<\cdot / \cdots 1\end{array}$ & نتيجه آزمون(فريدمن) & \\
\hline
\end{tabular}

نتايج مطالعه نشان دهنده تفاوت معنادار تغييرات نمرهى رفتار دادههاى تكرارى نيز نشان دهنده ى افزايش معنادار نمره ى رفتار

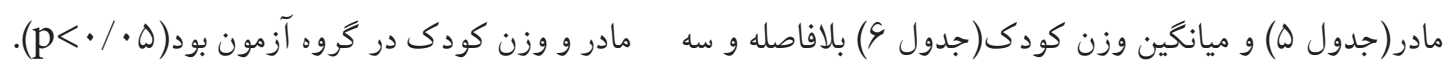

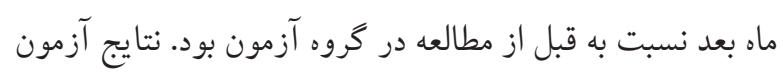
جدوله. تغييرات ميانه و دامنه ميان خاركى رفتار مادر در كروههاى آزمون و كنترل ، قبل، بلافاصله و سه ماه بعد از مداخله آموزشى تهون

\begin{tabular}{|c|c|c|c|c|}
\hline \multirow{2}{*}{$\begin{array}{l}\text { P-value } \\
\text { (من ويتنى) }\end{array}$} & كروه كنترل & كروه آزمون & \multirow{2}{*}{\multicolumn{2}{|c|}{ متغير }} \\
\hline & (دامنه ميان جار كى)ميانه & (دامنه ميان جاركى)ميانه & & \\
\hline $\begin{array}{l}Z=-r / 0 \cdot r \\
P<\cdot / \cdot r\end{array}$ & $\cdot(\cdot)$ & $r(\cdot)$ & تغييرات بلافاصله نسبت به قبل مداخله & \multirow{3}{*}{ رفتار مادر } \\
\hline $\begin{array}{l}\mathrm{Z}=-F^{\mathcal{F}} / \Delta F_{1} \\
\mathrm{P}<\cdot / \cdots 1\end{array}$ & $\cdot(-1)$ & $r(1)$ & تغييرات سه ماه بعد از مداخله نسبت به قبل & \\
\hline & $\begin{array}{l}X^{2}=\Delta / 4 \mu \\
p=\cdot / \cdot \varphi\end{array}$ & $\begin{array}{l}X^{2}=\mu F / F 1 \\
p<\cdot / \cdots 1\end{array}$ & نتيجه آزمون(فريدمن) & \\
\hline
\end{tabular}


جدول و. تغييرات ميانگين و انحراف معيار وزن كودى در گَروههاى آزمون و كنترل ، قبل، بلافاصله و سه ماه بعد از مداخله

\begin{tabular}{|c|c|c|c|c|}
\hline \multirow{2}{*}{$\begin{array}{l}\text { P-value } \\
\text { (تى مستقل) }\end{array}$} & كروه كنترل & كروه آزمون & \multirow{2}{*}{\multicolumn{2}{|c|}{ متغير }} \\
\hline & ميانگين土انحراف معيار & ميانگين土انحراف معيار & & \\
\hline $\begin{array}{c}\mathrm{t}=\wedge / \mathrm{r} \wedge \\
\mathrm{p}<\cdot / \cdots 1\end{array}$ & $19 r / \lambda \pm 9 r / 9$ & $119 / 1 F \pm \Lambda \Lambda / V$ & تغييرات بلافاصله نسبت به قبل مداخله & \\
\hline \multirow[t]{2}{*}{$\begin{array}{l}\mathrm{t}=s / \mathrm{rr} \\
\mathrm{p}<\cdot / \cdots 1\end{array}$} & $\Delta \Delta \Delta / 9 \vee \pm r \wedge r / 9$ & $9 \wedge 1 / \vee \cdot \pm r \vee r / f$ & تغييرات سه ماه بعد از مداخله نسبت به قبل & 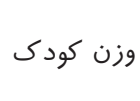 \\
\hline & $\begin{array}{l}\mathrm{f}=\mid \Delta \Lambda / F F \Delta \\
\mathrm{p}<\cdot / \cdots \mid\end{array}$ & $\begin{array}{c}\mathrm{f}=\mathrm{r} \Delta \mathrm{l} / \mathrm{v} \Delta \\
\mathrm{p}<\cdot / \cdots\end{array}$ & نتيجه آزمون(repeated measures) & \\
\hline
\end{tabular}

بִ

شده اند، به دليل اهميت به سلامت و رشد فرزندشان به عواقب رفتار خود توجه بيشترى نشان مى دهند.

سازه الكو سازى در مطالعه ى نجيمى و همكاران(YV) با نو عنوان همبستكى مصرف ميوه و سبزى با سازه هاى نظر يه شناختى اجتماعى در دانش آموزان با مطالعه ى ما همسو بود ولى اين سازه در مطالعات كر يمى و همكاران(1/) و عباسيان و همكاران(Y) افز ايش نيافت. در مطالعه ى عباسيان، احتمالاً به دليل كاهش دريافت ميوه و سبزى توسط والدين يا نداشتن دقت كافى مقياس به كار رفته براى ارزيابى الكوسازى، اين سازه افزايش نيافت(YT). سازه درك موقعيت در مطالعه ى بال و همكاران(YN)، انجم شعا و همكاران( (Y))، با نتيجه ى مطالعه ى ما همسو بود. در مطالعه ى حاضر، سازه محيط بعد از مداخله تغييرمعنى دارى در دو گروه نداشت. با توجه به عدم همكارى و شركت همسران در جلسات آموزشى ، از طرفى با توجه به اينكه بيش از نيمى از خانوادهها در

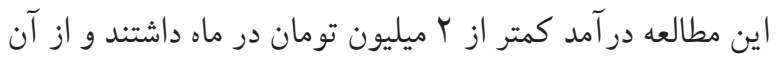
جا كه اين دو عامل مؤثر بر سازه محيط هستند، امكان مداخله ى مؤثر در اين زمينه فراهم نشد. هر جند در اين مطالعه تلاش شد با تشكيل كانال تلكر امى با حضور همسران و ارسال يِامهاى مرتبط در اين زمينه، درگير نمودن همسران در انجام تكاليف مربوط به كلاس آموزشى، حمايت همسران را جلب كرد ولى اين راهكار در

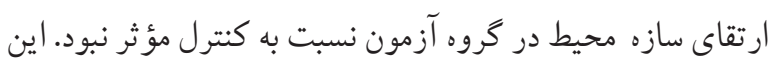
نتيجه با مطالعه ى عباسيان و همكاران همسو بود، در اين مطالعه
يافتهاى مطالعه ى حاضر نشان داد، مداخله ى آموزشى باعث افزايش معنى دار نمرات سازه هاى اين نظريه به جز سازه محيط در گروه آزمون شده است. سازه هاى خودكارآمدى، ارزش ييامد و آكاهى در مطالعات انجم شعا و همكاران( (Y)، عباسيان و همكاران(Y)( صفوى و همكاران(T) و رولينگ و هانگ(YF) بعد از مداخله افزايش معنى دار داشت و با يافته ى مطالعه يحاضر همسو بود. سازه ى خودتنظيمى در مطالعات بر انسكوم و شارما(Yه) با عنوان ييشگو يى كنندهاى مصرف ميان وعده در ميان كود كان با استفاده از نظر يه شناختى اجتماعى و انجم شعا و همكاران( (Y) افزايش يافت ولى در مطالعه ى رنكرت و همكاران(Yצ) با عنوان ارزشيابى مداخله آموزشى بر اساس نظريه شناختى اجتماعى در ارتقاى فعاليت جسمى افزايش نيافت. كو تاه بودن مرحله ى ييخيرى در اين مطالعه كه يكماه در نظر گرفته شده بود يا عدم همكارى فراخيران گِ از مداخله، احتمالاً دليل عدم افزايش اين سازه در اين مطالعه بوده است. ميانگين سازه انتظار بيامد در مطالعه ى انجم شعاو همكاران(Y) افزايش يافت اما در مطالعه ى عباسيان و همكاران(Yr) افزايش معنى دار نداشت. به نظر مى رسد متفاوت بودن شرايط سنى، نوع گروه هدف و نوع مداخله در اين مطالعه دليل احتمالى اين موضوع مى تواند باشد. زيرا گروه هدف در مطالعه ع عباسيان، نوجوانان بوده كه بر خلاف بزركسالان به آينده و نتيجه ى رفتار در آينده توجهى ندارند(YT) ولى گروه هدف در مطالعه ى حاضر، مادر هستند كه ضمن اينكه دوران نوجوانى راطى كرده و وارد جوانى و بزر كسالى 
مثبت آموزش بر وزن كودى بود.يافتهاى مطالعه ى حسين و رحمان با عنوان نقش آموزش والدين در كاهش شيوع سو ء تغذيه بوديه

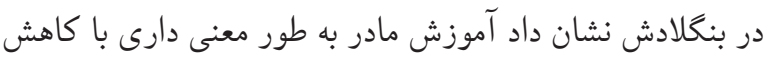

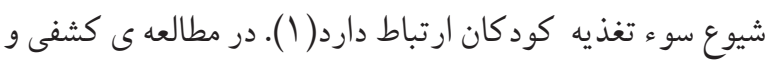

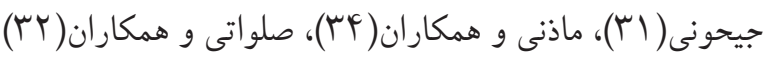

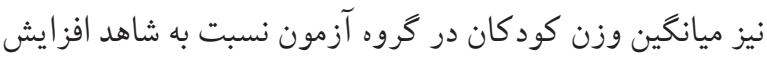

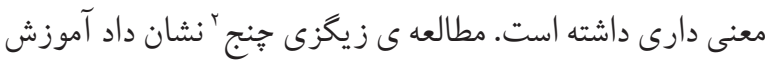
مادر عامل مؤثر بر رشد كودكان آI ماهه مناطق روستايى جين

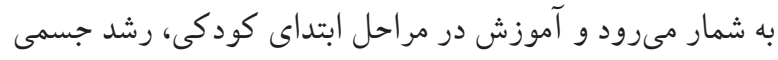

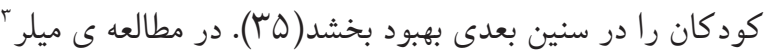

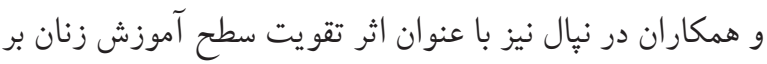

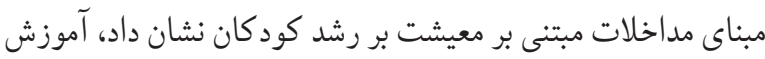

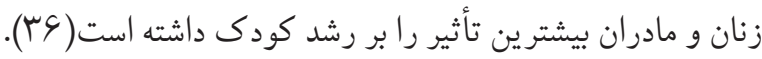

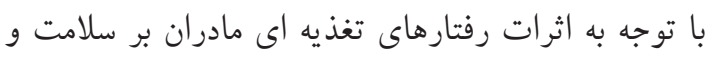

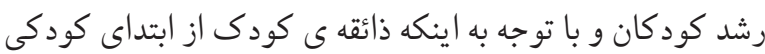

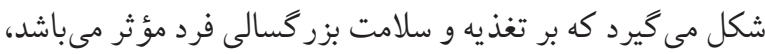

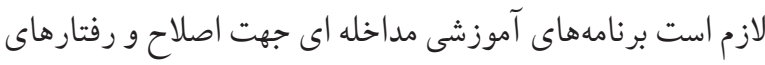

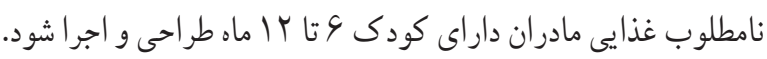
هماند ساير مطالعات اين مطالعه نيز محدوديت هايى به همراه

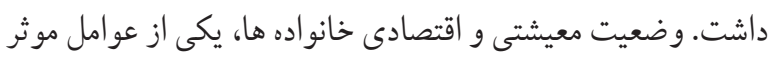

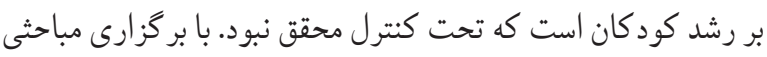

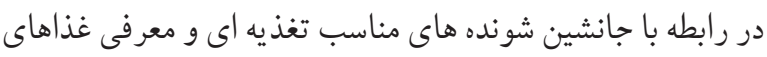
با ارزش غذايى يكسان ولى ارزانتر، سعى شد تا اين محدوديت

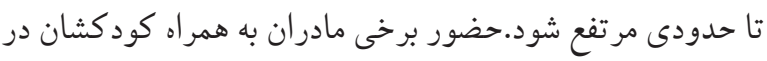

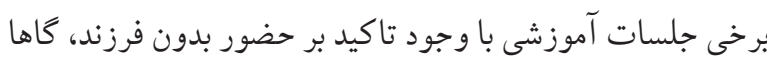

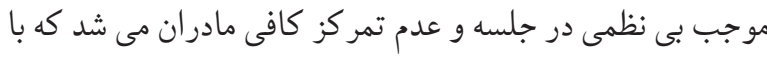

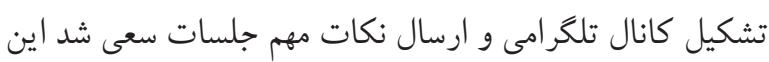
محدوديت رفع شود. تفاوت در سطوح شناختى و روانى شر كت

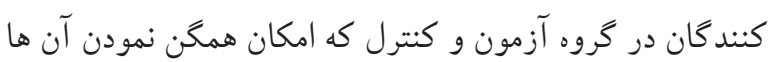
از اين جهت دشوار بود. فراهمى آن در خانواده با توجه به اينكه والدين مسئول خر يد مواد غذايى در خانه هستند، دلايل احتمالى عدم افزايش اين سازه ذكر شده است(Y (Y). سازه محيط در مطالعات امينى و همكاران (Yq) و انجم شعا و همكاران(YT) افزايش يافت. در نتايج اين يثوهش حاكى از آن بوده كه نمره ى ساز كارى عاطفى در طول مطالعه در كروه آزمون، اختلاف معنادارى بيدا كرده است. اما اختلاف ميانه ى اين سازه در گروه كنترل معنادار نبود كه مبين اين است كه برنامه آموزشى طر احى شده باعث ارتقاى اين سازه شده است. شاييرو و همكاران نيز در مطالعه ى خود نشان دادند آموزش در دانشجويان رشته ى روانشناسى توانست استرس اين افراد را كاهش دهد.(·) يافتهاى يزوهش حاضر در رابطه با متغير رفتار مادر نشان دهنده ى تأثير مثبت آموزش بر رفتار مادر بود. مطالعه اي كه با عنوان آموزش يايش رشد تنظيم شده بر اساس الخوى پيرسيد به مادران در يِشخيرى از اختلال رشد كودكان 9 تا با ماهه توسط كشفى و جيحونى انجام شد، نشان داد ميانكين امتياز عملكرد مادران در كروه آزمون نسبت به شاهد افزايش معنى دارى داشته است( آY). نتايج بررسى انجام شده توسط عباسيان و همكاران

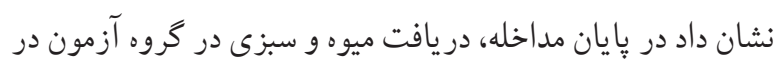

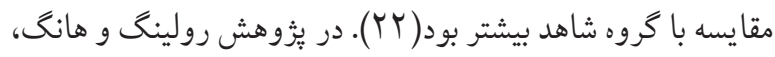
سازه هاى نظريه شناختى اجتماعى نقش موثرى بر رفتار تغذيه اى كود كان داشت(YF). صلو اتى و همكاران، انجم شعاو همكاران نيز در يثزوهش خود نشان دادند آموزش با تاكيد بر رفتار تغذيه اي موجب بهبود عملكرد مادران شده است(Yr). نتايج مطالعه ى آريكيو' و و همكاران نيز نشان دهندهى تأثير آموزش بر بهبود روشهاى تغذيه تكميلى در كود كان زير F T ماه بود(سT). در مطالعه ى انجم شعاو همكاران نيز، عملكرد تغذيه اي مادران دار ایى كودك و تا ب ماه، يس از مداخله آموزشى افزايش معنادارى يافت( آY). يافتههاى يزّوهش حاضر در رابطه با متغير وزن كودك نشان دهنده يى تأثير 


$$
\begin{aligned}
& \text { رشد كودك بيشتر است) يا مادران داراى كودك مبتلا به اختلال } \\
& \text { رشد با بيمارى هاى خاص ريشنهاد مى شود. }
\end{aligned}
$$

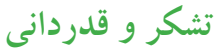

$$
\begin{aligned}
& \text { اين مقاله بخشى از يايان نامه دانشجويىى كارشناسى ارشد مىباشد . } \\
& \text { كد اخلاق اين مطالعه IR.MUMS.REC.1397.028 در معاونت } \\
& \text { يزوهشى دانشخاه علوم يزشكى مشهد ثبت شده است و كد تأييد } \\
& \text { آن IRCT20160917029843N12 در سايت كارآزمايى بالينى } \\
& \text { ايران به ثبت رسيده است. از همكارى مسئولين معاونت بهداشتى } \\
& \text { دانشگاه علوم يزشكى تربت حيدريه ، مراقبين پِايخادهاى سلامت } \\
& \text { و مادران شركت كننده در مطالعه تشكر و قدردانى مى شود. }
\end{aligned}
$$

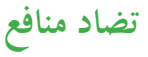

$$
\begin{aligned}
& \text { نويسندگان تصريح مى كنند كه هيج گونه تضاد منافعى در مطالعه } \\
& \text { حاضر وجود ندارد. }
\end{aligned}
$$

\section{Refrences}

1. Amel Barez M, Maleki Saghouni N, sharifi F, Esmaily $H$, Babazadeh R. Investigation the relationship between selfesteem and breastfeeding self-efficacy in primiparous breastfeeding mothers referring to Mashhad medical centers. Journal of Health Literacy. 2020;5(3):36-45.

2. Williams AM, Suchdev PS. Assessing and improving childhood nutrition and growth globally. Pediatric Clinics. 2017;64(4):755-68. https://doi.org/10.1016/j.pcl.2017.03.001

3. Hazavehi $\mathrm{m}$, Taheri $\mathrm{m}$, Moeini $\mathrm{b}$, Roshanaei g. Investigating causes of the infants' growth disorder (6-12 months) in Hamadan health centers based on Health Belief Model. Avicenna Journal of Nursing and Midwifery Care. 2013;21(3):68-76.

4. Schwarzenberg SJ, Georgieff MK. Advocacy for improving nutrition in the first 1000 days to support childhood development and adult health. Pediatrics. 2018;141(2). https://doi.org/10.1542/peds.2017-3716

5. Moradi F, Babazade T, Zebae N. Impact of Educational Intervention on Mothers Empowerment about Proper Nutrition among Infants under 2 years of age Covered By Health Homes of District 18 of Tehran Municipality. Iranian Journal of Health Education and Health Promotion. 2014;2(3):242-50.

6. Sachs JD. From millennium development goals to sustainable development goals. The lancet. 2012;379(9832):2206-11. https://doi.org/10.1016/S0140-6736(12)60685-0

7. Organization WH. UNICEF/WHO/The World Bank Group joint child malnutrition estimates: levels and trends in child malnutrition: key findings of the 2020 edition. 2020.

8. Khabiri R, Khosravi A, Elahi E, Khodayari Moez E, Rashidian A. Maternal Health Care based on Iran' Multiple Indicator Demographic and Health Survey (IrMIDHS-2010). Hakim Research Journal. 2014;17(1):67-77.

9. Abdalmaleki E, Abdi Z, Gohrimehr M, Alvandi R, Riazi Isfahani S, Ahmadnezhad E. Multiple Indicator Clustar Survey and Demographic and Health Survey in the Eastern Mediterranean Region: What Is the Iran's Situation in Terms of Implementation? Iranian Journal of Epidemiology. 2020;16(2):108-21.

10. WagstaffA, Watanabe N. Socioeconomic inequalities in child malnutrition in the developing world. The World Bank;2000. https://doi.org/10.1596/1813-9450-2434

11. Keane E, Layte R, Harrington J, Kearney PM, Perry IJ. Measured parental weight status and familial socioeconomic status correlates with childhood overweight and obesity at age 9. PLoS One. 2012;7(8):e43503. https://doi.org/10.1371/journal.pone.0043503

12. Abbott $\mathrm{MB}$, Vlasses $\mathrm{CH}$. Nelson textbook of pediatrics. Jama. 2011;306(21):2387-8. 
https://doi.org/10.1001/jama.2011.1775

13. van Ansem WJ, Schrijvers CT, Rodenburg G, van de Mheen D. Maternal educational level and children's healthy eating behaviour: role of the home food environment (cross-sectional results from the INPACT study). International Journal of Behavioral Nutrition and Physical Activity. 2014;11(1):1-12. https://doi.org/10.1186/s12966-014-0113-0

14. Karen Glanz BKV, Sons JW. Health Behavior and Health Education: Theory, Research, and Practice. 4, editor2008. p.592

15. Nutbeam D, Harris E, Wise W. Theory in a nutshell: a practical guide to health promotion theories: McGrawHill; 2010

16. Bashirian S, Jalili M, Karimi-shahanjarini A, Soltanian A, Barati M. Effectiveness of Educational Program Based on Social Cognitive Theory Constructs to Promote Nutritional Behaviors among Pregnant Women in Tabriz. Iranian Journal of Nutrition Sciences \& Food Technology. 2017;12(3):1-10.

17. Peyman N, Mahdizadeh M, Taghipour A, Esmaily H. Using of social cognitive theory: predictors of physical activity among women with diabetestype 2. Journal of Research and Health. 2013;3(2):345-54

18. Karimi-Shahanjarini A, Sharifi M, Bashirian S, Moghimbeigi A. Determinants of Healthy Snacks Choice by Mothers of 1-5 years old children in Hamadan Based on Social Cognitive Theory (SCT). Iranian Journal of Nutrition Sciences \& Food Technology. 2015;9(4):19-26.

19. Larson NI, Neumark-SztainerDR,StoryMT, WallMM, Harnack

LJ, Eisenberg ME. Fast food intake: longitudinal trends during the transition to young adulthood and correlates of intake. Journal of adolescent health. 2008;43(1):79-86. https://doi.org/10.1016/j.jadohealth.2007.12.005

20. Golshiri P, Sharifirad G, Baghernezhad F. Comparison of two methods of education (lecture and self learning) on knowledge and practice of mothers with under 3 year old children about growth monitoring and nutritional development stages. Iranian Journal of Medical Education. 2011;10(5):927-36.

21. Anjomshoa H, Mirzai M, Iranpour A. The Application of Social Cognitive Theory on Mothers' Feeding Practices for Children Aged 6 to 24 Months old in Iran. International Journal of Pediatrics. 2018;6(7):7983-97.

22. Abbasian F, Omidvar N, Bondarianzadeh D, Rashidkhani B, Shakibazadeh E, Hashemi B. Effect of a school-based intervention based on social cognitive theory on fruit and vegetable consumption in middle school students in
Tehran. Journal of hayat. 2012;17(4):73-84.

23. Yahyavi SH, Pourrahimi M. Impact of dietary behaviors and exercise activities education on the self-efficacy of middle school students. Medical Science Journal of Islamic Azad Univesity-Tehran Medical Branch. 2012;22(2):143-51.

24. Rolling TE, Hong M. The effect of social cognitive theory-based interventions on dietary behavior within children. J Nutrition Health Food Sci. 2016;4(5):1-9.. https://doi.org/10.15226/jnhfs.2016.00179

25. Branscum P SM. Predictors of Snack Food Consumption Among Upper Elementary Children Using Social Cognitive Theory. Journal of Social, Behavioral and Health Sciences. 2011;5(1):23-37.

26. Rengert, Julie "Development and Evaluation of a Social Cognitive Theory-Based Exercise Intervention in Firefighters: 5-ALARM Fitness Program." Electronic Thesis or Dissertation. Ohio State University, 2011. https://etd. ohiolink.edu/

27. Arash Najimi, Mohtasham Ghaffari, Masoume Alidousti. Social cognitive correlates of fruit and vegetables consumption among students: a cross-sectional research. Pajoohande. 2012;17(2):81-6.

28. Ball K, Bauman A, Leslie E, Owen N. Perceived Environmental Aesthetics and Convenience and Company Are Associated with Walking for Exercise among Australian Adults. Preventive Medicine. 2001;33(5):434-40. https://doi.org/10.1006/pmed.2001.0912

29. Amini Moridani M, Tol A, Sadeghi R, Mohebbi B, Azam K. Assessing the Effect of Family-based Intervention Education Program on Perceived Social Support among Older Adults with Type 2 Diabetes: Application of Social Cognitive Theory. Journal of Nursing Education. 2015;4(3):30-40.

30. Shapiro SL, Brown KW, Biegel GM. Teaching self-care to caregivers: Effects of mindfulness-based stress reduction on the mental health of therapists in training. Training and Education in Professional Psychology. 2007;1(2):105-15. https://doi.org/10.1037/1931-3918.1.2.105

31. Kashfi SM, Khani Jeyhouni A. Mothers' educational program based on the precede model on the prevention of growth retardation in 6 to 12-month old children in the health centers of Shiraz city, Fars Province, Iran: An Interventional Study. Journal of School of Public Health and Institute of Public Health Research. 2012;9(3):55-62.

32. Salavati Ghasemi S, Cheraghi F, Hasan Tehrani T, Moghimbeigi A. The effect of mothers' feeding behavior education on eating habits of their toddler children in Hamadan kindergartens. Iranian Journal of Pediatric 
Nursing. 2015;2(2):68-79.

33. Arikpo D, Edet ES, Chibuzor MT, Odey F, Caldwell DM. Educational interventions for improving primary caregiver complementary feeding practices for children aged 24 months and under. Cochrane database of systematic reviews. 2018(5). https://doi.org/10.1002/14651858.CD011768.pub2

34. Mazani M HAY, Nemati A, Mash'oufi M, Mahdavi R. Comparing the Effectiveness of Attendance and Non Attendance Education of Health Workers on Knowledge of Mothers and Anthropometric Changes of Infants. journal of health. 2012;3(1):74-86.
35. Cheng Z, Shi L, Li Y, Wang Y, Zhang J. Using structural equation modelling to assess factors influencing children's growth and nutrition in rural China. Public health nutrition. 2018;21(6):1167-75. https://doi.org/10.1017/S1368980017003494

36. Miller LC, Joshi N, Lohani M, Rogers B, Mahato S, Ghosh $S$, et al. Women's education level amplifies the effects of a livelihoods-based intervention on household wealth, child diet, and child growth in rural Nepal. International journal for equity in health. 2017;16(1):183 https://doi.org/10.1186/s12939-017-0681-0 